\title{
Distinkce a bydlení v pozdně socialistické společnosti
}

\author{
Distinction and Housing during the Late Socialist Society \\ Ondřej Špaček
}

\begin{abstract}
Housing consumption practices belong to everyday distinctive ways of expressing status position. Approaching the topic from the consumption practices perspective, this paper aims to reconstruct the relationship between social space and housing in Czech society during late socialism. Large scale representative surveys conducted in 1977 and 1984 are employed to answer the following questions: (1) to what extent was the field of housing structured by dimensions of social space, especially by political, cultural, and economic capital? (2) to what extent were housing preferences structured by this social space? and (3) what is the position of cottage practices in the field of housing consumption? Results reveal the crucial importance of cultural capital, which is intimately connected with rural-to-urban migration, as those with more cultural capital often lived in flats of higher quality and cottage usage was more widespread among them. Discussion focuses on the applicability of habitus and cultural capital as concepts for the study of urban-rural differences and emphasizes the pitfalls of employing housing preference analysis without taking into consideration the existing housing structure.
\end{abstract}

KEYWORDS Housing, consumption, social space, taste, socialism, Czech Republic

Způsoby bydlení a praktiky jeho budování představují jednu z výrazných a zároveň každodenních cest vyjadřování statusové pozice (Bourdieu 1984, 2005; Silva a Wright 2009). Zkoumání vztahu mezi pozicemi v sociálním prostoru a zpo̊sobem bydlení přitom může být př́nosné nejen pro porozumění spotřebním praktikám v domácnosti (Southerton 2001), ale také pro studium procesů proměňujících město (napřr. gentrifikace či suburbanizace; Bridge 2006b; Bourdieu 2005) či pro výzkum sociálních nerovností (Silva a Wright 2009). Následující příspěvek se z této perspektivy pokouší rekonstruovat vztah mezi bydlením a sociálním prostorem v české společnosti pozdního socialismu, a přispět tak nejen k porozumění nedávné minulosti, ale i k lepšímu pochopení urbánních procesů.

Spotřeba a domov jsou úzce propojené oblasti. Domov představuje nezbytné místo pro řadu spotřebních praktik, jako jsou například vaření či sledování televize, a stejně tak je představa domova do značné míry s těmito aktivitami spojena (srov. Blunt a Dowling 2006; Money 2007; Southerton 2001). Široká pozornost, která je věnována dotváření a designu vlastního bydlení, ukazuje, že se jedná o významný zdroj vlastní identity, ale i podstatný prostor pro komercializovanou spotřebu. Podobně jako hudba, sport či cestování jsou přitom

Sociální studia. Katedra sociologie FSS MU, 4/2014. S. 51-70. ISSN 1214-813X. 
praktiky bydlení zakotveny sociálně (srov. Warde 2005). Ze sociologického pohledu se nejedná o „navýsost individuální svět“, místo „splynutí s lidstvím v jeho nepopsatelných proměnách“ (Lux a Kostelecký 2011: 7), ale prostor plný sociálně definovaných a sdílených významů, které sice mohou být $\mathrm{v}$ konkrétních př́ípadech jedinečně kombinovány, ale tato variabilita by nás neměla odvádět od sociální zakotvenosti privátní sféry. Bourdieu a jeho následovníci přitom upozorňují na úzkou propojenost praktik a stratifikačních procesů (Bourdieu 1984; Swartz 1997; Bennett a kol. 2009). Skrz tř́́dně podmíněný habitus, který se projevuje v odlišném vkusu, volí různí lidé různé spotřební praktiky. Tyto praktiky jsou zároveň předmětem hodnocení ze strany ostatních, které je podmíněno habitem, a tím reprodukují a utvrzují třídní strukturu ve společnosti.

Ekonomická nákladnost bydlení posiluje tendenci chápat rozhodnutí, které v této oblasti domácnosti činí, především jako otázku finanční. Řada př́padů ale ukazuje, že samotné definování toho, co je „dobré“ a „žádoucí“ bydlení, a co tedy bude poptáváno, je sociálně podmíněno. Rodinný dům se zahradou nemusí ztělesňovat univerzální představu blahobytu. Lze ukázat, nakolik se představa ideálu suburbánního bydlení vynořuje jako ztělesnění hodnot britské střední třídy v průběhu 19. století (Vacková 2013), anebo je výsledkem komplexních interakcí mezi developerem, státem a potenciálními zákazníky (Bourdieu 2005). To neznamená, že ekonomické nerovnosti nejsou pro studium bydlení podstatné, naopak. Zároveň lze ale konstatovat, že i se stejným objemem finančních zdrojů je možné realizovat bydlení $\mathrm{v}$ různých formách a podobách.

Bourdieuovská perspektiva poskytuje platformu, na které se daří organicky propojovat zájem badatelů $\mathrm{v}$ oblasti města a sociálních nerovností. Habitus formovaný sociální pozicí se ukazuje jako významný odlišující moment například při posuzování ideálu bydlení (GramHanssen a Bech-Danielsen 2004; Silva a Wright 2009), v pocitu přináležitosti k bydlišti (Savage a kol. 2010), při hledání rovnováhy mezi estetickou stránkou bydlení a vzdělávacími možnostmi dětí (Bridge 2006a) či při hledání (Boterman 2012) a prodeji (Bridge 2001) nemovitostí. Př́stup přináší významnou sociologickou inspiraci pro převážně ekonomisticky orientované výzkumy bydlení (Savage a kol. 2010). ${ }^{1}$

\section{Bydlení a nerovnosti $v$ době pozdního socialismu}

Východiskem tohoto výzkumu je teze, že socialistické Československo, přes nivelizaci př́ijmů a všudypř́ítomné deklarování eliminace trrídních rozdílů jako takových, nepředstavovalo

Tento prrístup ke studiu nerovností a bydlení se ve svých východiscích odlišuje od konceptu tříd bydlení (housing classes), který formulovali Rex a Moore v 60. letech (viz Musil 2003). Koncept tříd bydlení chápe povahu právního vztahu k vlastnímu bydlení jako klíčovou stratifikační charakteristiku, která je ve společnosti nerovně distribuována a na základě které tak, podle těchto autorů, je možné analyzovat sociální strukturu současné společnosti. Tato perspektiva se setkala s určitým kritickým ohlasem i v kontextu české sociologie (Kostelecký 2005; Lux, Sunega a Katrňák 2013; Šafr 2006), je ale nutné zdůraznit, že v tomto textu není bydlení nahlíženo pouze jako potenciální zdroj ve stratifikačním systému, ale spíše jako jedna z oblastí sociální diferenciace spotřeby (srov. Warde 2005), kde se může projevovat rozdílnost habitu prostřednictvím odlišných preferencí či vkusu. 
společnost bez nerovností. Těmito nerovnostmi přitom nejsou myšlena výhradně privilegia stranické elity, která se v zásadě omezovala na relativně malou skupinu nejvyšších funkcionářò. Významné a přetrvávající rozdíly se totiž zakládaly i na akumulaci kulturního kapitálu, který se stává podstatným zdrojem třídních rozdílů $\mathrm{v}$ moderních, obzvláště pak stř̌edoevropských společnostech (Eyal, Szelényi a Townsley 1998). Přes snahu komunistické vzdělávací politiky intervenovat do mechanismů mezigenerační reprodukce vzdělání lze na základě empirických analýz konstatovat, že i většině rodin s „,nevhodným“ tř́́dním původem se dařilo přenášet kulturní kapitál z generace na generaci (Andrle 1999; Kreidl 2008). Podobně lze spolu s Možným (1999) uvažovat o výrazné symbolické hranici vytvářené právě rozdílným objemem kulturního kapitálu mezi „obyčejným“ člověkem a tehdejšími disidenty. ${ }^{2}$ Jedním ze způsobů, jak tedy lze charakterizovat prostor pozdně socialistické společnosti, je proto nejen v dimenzích politického, ale také kulturního kapitálu (Bourdieu 1998; Eyal, Szelényi a Townsley 1998).

Tento problém lze teoreticky rámovat probíhající diskuzí o problematickém oddělení „ekonomického“ a „sociálního“ ve výzkumu sociální stratifikace (Bottero 2005: 52-67). Můžeme tak uvažovat o tom, zda potlačení ekonomických nerovností v době socialismu (př́ijmová nivelizace, zrušení soukromého vlastnictví) muselo nutně eliminovat i kulturně a sociálně reprodukované rozdíly mezi lidmi, nebo tyto rozdíly nezmizely a dále se reprodukovaly v každodenním životě, tedy např́íklad i v oblasti bydlení.

Na rozdíl od geografických vzorců a prostorové diferenciace socialistického města (srov. např. Matějů, Večerník a Jeřábek 1979; Musil 1987; Smith 1996; Szelényi 1983) se přímé analýze diferenciace bydlení a postojů $\mathrm{k}$ bydlení na úrovni jednotlivců $\mathrm{v}$ kontextu socialistické společnosti nevěnovala př́lišná pozornost. ${ }^{3}$ Předmětem studia byla především morfologie měst a jejich sociální ekologie, naopak opomíjeny byly podstatné mechanismy reprodukce těchto městských struktur na úrovni jednotlivců (srov. Musil 1991). Tyto mechanismy se odvíjely především od socialistické bytové politiky, která chápala bydlení jako veřejný statek, který má být zajišstován a garantován státem. Distribuci tohoto statku stát reguloval prostřednictvím svých institucí, přičemž klíčovou roli zde sehrávaly tzv. pořadníky žadatelů o byt, které sestavovaly bytové komise. Vzhledem $\mathrm{k}$ řadě paralelních kritérií pro přednostní pořadí, neprůhlednosti rozhodování a existenci dalších hospodářských a politických tlaků není zcela zřejmé, jak vlastně toto rozdělování probíhalo. Bez studia protokolů samotných bytových komisí tak o reálných prioritách socialistické bytové politiky můžeme usuzovat pouze nepř́mo, na základě skladby obyvatel nových a starých bytů (Musil 2002: 279-280).

Jedním z mála empirických př́spěvků, který se tomuto tématu věnuje, je Szelényiho (1983) analýza propojující studium městské struktury a sociálních nerovností v době socialismu. Szelényi na základě dostupných dat rozpoznává mechanismy třídních nerovností, které se významným způsobem projevují právě v distribuci bydlení. Zatímco v kapitalistických

2 Tím nemá být řečeno, že si pod nositeli kulturního kapitálu v následující analýze máme představit zejména disidenty. Spíše se jedná o širokou vrstvu technické inteligence, odborníků, kulturních pracovníků či třeba lékařů a právníků (srov. Eyal, Szelényi a Townsley 1998).

3 Etnografické studie bydlení v socialistickém Československu se zaměřují především na panelová sídliště (Barvíková 2010; Ferenčuhová a Jayne 2013) a otázky nerovností explicitně netematizují. 
společnostech rozdíly v bydlení odráží př́ijmové nerovnosti, tak v socialistických zemích distribuce bydlení spíše nerovnosti ustanovuje, jedná se o formu privilegií (Szelényi 1983: 8-9). V situaci, kdy je nové bydlení nedostatkovým statkem, vede administrativní alokace bytů $\mathrm{k}$ tomu, že nejčastěji budou uspokojovány požadavky žádanějších, a tudíž i lépe postavených profesí. Ostatně, ,jak by mohl stát ríkat svým řídícím pracovníkům a úředníkům na vzestupu: „Pokud budete povýšeni, snižite své šance na bydlení““ (Szelényi 1983: 10). Tento teoreticky zdůvodněný mechanismus nerovností Szelényi empiricky potvrdil na dostupných datech ze socialistických zemí střední a východní Evropy. Při přenosu těchto poznatkủ do českého kontextu ale zůstávají k zodpovězení dvě otázky: (1) nakolik se v těchto mechanismech projevila specifika československého socialismu, který byl i na poměry zemí východního bloku extrémně ekonomicky nivelizovaný; (2) nakolik byl efekt pozorovaný Szelényim typický pro ranější fáze socialistické masové výstavby bytů (použitá data jsou převážně z konce 60. a začátku 70. let) a nakolik následné rozšiřování výstavby a širší uspokojování poptávky mohlo popisované nerovnosti snížit (srov. Bodnár a Böröcz 1998)?

Praktiky spojené $\mathrm{s}$ domovem a bydlením nelze $\mathrm{v}$ době socialismu omezit pouze na samotný byt či domek. V kultuře socialistické společnosti hrál nezanedbatelnou úlohu fenomén chataření a chalupaření (Bren 2002; Librová 1975). Ten je přitom možné považovat nejen za způsob rekreace, ale také za extenzi domova, místo, které má podobné charakteristiky a naplňuje podobné potřeby jako vlastní byt. V kontextu toho, že většina obyvatel neměla $\mathrm{v}$ této době možnost volně disponovat vlastním bytem, je možné formulovat tezi, že právě chaty a chalupy mohly být relativně svobodným místem realizace vlastní identity (Bren 2002). Osvojený habitus se zde mohl projevovat nejsilněji a zároveň mohl být také ostatními klasifikován. ${ }^{4}$ Librová (1975) ostatně ve svém rozlišení chataření a chalupaření ukazuje na významné odlišnosti v podobě a významu těchto praktik, stejně jako na odlišnou sociální skladbu jejich nositelů, byt' pouze na omezeném vzorku případových studí. Zatímco podle ní byli chalupáři převážně vzdělanější, více orientovaní na rozvoj svého druhého bydlení a více zapojení v místní komunitě, u chatařu konstatuje spíše orientaci na soukromou rekreaci (srov. též Bren 2002). Přestože tato perspektiva studia druhého bydlení nebyla dále rozvíjena, představuje tento fenomén sám o sobě pozoruhodný aspekt praktik bydlení, který by neměl být v následující analýze opominut.

Celkově lze rríci, že prostředí společností střední a východní Evropy v období pozdního socialismu představuje specifický př́ípad, na kterém je možné studovat otázky sociálního kontextu bydlení v nezvyklém světle. V prvé řadě je zřejmé, že socialistická organizace bytové politiky do značné míry potlačila roli ekonomického kapitálu jako zdroje pro zajištování bydlení. O to naléhavější je pak otázka, nakolik jiné zdroje uplatňované $v$ těchto společnostech zejména pak politický a kulturní kapitál - strukturovaly prostor bydlení. Budeme tedy hledat odpověd' na to, jakým způsobem dimenze sociálního prostoru souvisely se způsobem bydlení.

Druhá otázka směřuje $\mathrm{k}$ tomu, jaké preference a očekávání se $\mathrm{v}$ tomto kontextu formovaly a jakým způsobem byly spojeny s různými sociálními pozicemi. Tedy s jakým pohledem

$4 \quad$ Na samotě u lesa (1976) představuje klasické filmové dílo, které zachycuje praktiky chalupaření, ale především variabilitu habitů, které se zde projevovaly. Zároveň je v něm možné vyčíst i určitou distanci, kterou hrdina filmu má vůči jiným podobám této praktiky. 
a hodnocením způsobu bydlení byly spojeny privilegované pozice ve společnosti a jak tento pohled mohl souviset se strukturou dostupného bydlení. Konkrétněji pak zde lze hledat odpověd’ na otázku, jaká hodnota byla prrikládána bydlení v rodinných domech, či naopak na panelovém sídlišti či v tradiční městské zástavbě. Neopomenutelné přitom bude i posouzení rozdílů v preferencích bydlení ve větším městě či v menších obcích.

Tato analýza by byla neúplná, pokud by nebyla věnována pozornost i třetí otázce, a to roli chataření a chalupaření ve výše uvedené diferenci. Právě tyto rekreační objekty totiž představovaly místa relativně volného nakládání a reálného vlastnictví, prostřednictvím kterých mohlo být symbolické vymezování skupiny realizováno.

\section{Data a metody}

Pokud chceme při analýze sociální diferenciace preferencí v bydlení dostát přístupu, který propaguje Bourdieu ve svých analýzách sociálního prostoru, dostáváme se zároveň do konfliktu s převažujícími statisticko-analytickými nástroji, jako je např́ílad regresní analýza, které spočivají v hledání kauzálních vysvětlení prostřednictvím rozlišení závisle a nezávisle proměnných. Bourdieu (např. 1984: 101-106; též Bennett a kol. 2009: 31-33; Wuggenig 2007) kritizuje pozitivistický př́stup kvantitativních analýz založených na snaze izolovat vliv nezávisle proměnných, které jsou $\mathrm{v}$ reálném sociálním světě neoddělitelně provázané. $\mathrm{Z}$ těchto důvodů využívá, a jeho následovníci dále rozvíjí, metodu vícerozměrné korespondenční analýzy, která nerozděluje proměnné jako příčiny a následky, ale zaměřuje se na hledání existujících struktur $\mathrm{v}$ mnoharozměrných datech (podrobněji Roux a Rouanet 2004; Bennett a kol. 2009; srov. Breiger 2000). Bourdieu navrhuje prostřednictvím této statistické metody nejdříve konstruovat sociální prostor na základě spoluvýskytu určitého typu či podob nejrůznějších praktik a až následně identifikovat klíčové dimenze takto vytvořeného prostoru a př́padný soulad těchto dimenzí s relevantními kapitály.

Pro následující analýzu nejsou $\mathrm{k}$ dispozici vhodná data, která by umožňovala geometrickým př́stupem korespondenční analýzy rekonstruovat prostor s „oblaky bodů“. Projevuje se zde nutné omezení analýzy založené na autentických reprezentativních datech z minulosti, jejichž podobu nebylo pochopitelně možné přizpůsobit východiskům této studie. Na druhou stranu je sama Bourdieuova teze o nevhodnosti tradiční statistické analýzy pro některé typy sociologických dat relevantní a závažná. Vzájemná provázanost vazeb a komplexita př́ičinnosti do značné míry zpochybňuje možnost jednoznačně formulovat model, kde určitá sada proměnných je vysvětlující a jiná vysvětlovaná. Př́kladem může být komplikovaný vztah mezi dosaženým vzděláním a místem bydliště, ve kterém hrají roli koncentrační tendence vzdělávacích příležitostí i kvalifikovaných pracovních míst, selektivní mobilita během životního cyklu, odlišné hodnoty a kultura měst a venkova, zakotvenost rodinného nemovitého majetku a řada dalších faktorů, které znejasňují, co lze ve statickém průřezovém šetření považovat za př́ícinu a co za následek.

$\mathrm{Z}$ těchto důvodů je dále kladen důraz především na relativně jednoduché, $\mathrm{v}$ určitém slova smyslu deskriptivní analýzy pomocí kontingenčních tabulek spíše než na vícerozměrné regresní modely. Tento př́stup umožňuje potvrzovat existenci určitých vztahů mezi proměnnými, aniž by nutně musel vycházet $\mathrm{z}$ určité představy o kauzalitě. Neznamená to 
přitom, že by analýza rezignovala na statistické testování zjištění. Naopak, potvrzení statistické relevance zjištěných rozdílů bylo pečlivě provedeno a při prezentaci výsledků je schematicky znázorňováno. ${ }^{5}$

Analýza se opírá o dva datové soubory z dotazníkových šetření uskutečněných v roce 1984 a částečně též o šetření pražského obyvatelstva z roku 1977. ${ }^{6}$ První dva zmiňované výzkumy byly součástí širšího projektu, který se zabýval šetřením třídní a sociální struktury tehdejší společnosti. První, rozsáhlejší soubor se zaměřoval především na podrobné mapování sociální struktury v nejrůznějších aspektech života (TSS 1984, N = 11 713), druhý se pak soustředil na postoje, které s těmito oblastmi souvisí (TSS 1984 Postoje, $\mathrm{N}=2253$ ). ${ }^{7}$ V obou případech využíváme $\mathrm{z}$ těchto datových souborů pouze respondenty z tehdejší ČSR starší 18 let. Třetí použitý soubor představuje doplňkový zdroj. Jedná se o reprezentativní šetření obyvatel Prahy starších 18 let, které se zaměřuje na životní prostředí a způsob bydlení (Životní prostředí Prahy 1977, N = 1 995).

Sociální prostor české společnosti v době socialismu lze charakterizovat především prostřednictvím politického a kulturního kapitálu. Přestože význam ekonomického kapitálu byl vzhledem k potlačení tržních mechanismů a soukromého vlastnictví oproti západním společnostem podstatně menší, je do analýzy zařazen také. Tyto tři dimenze sociálního prostoru jsou operacionalizovány v podstatně zjednodušené podobě. Kulturní kapitál je reprezentován výhradně svou institucionalizovanou dimenzí jakožto nejvyšší dosažené vzdělání respondenta. Komplexnější ukazatel zahrnující i další indikátory (zpơsob trávení volného času, vlastnictví knih) nebylo možné zkonstruovat ve všech použitých souborech a jeho použití v jednotlivých analýzách nevedlo k podstatně odlišným výsledkům. Zároveň se ukazuje (srov. Kreidl 2008), že politická omezení studijních příležitostí nepředstavovala zásadní překážku, která by zpochybňovala věrohodnost dosaženého vzdělání jako indikátoru kulturního kapitálu. Politický kapitál je odvozen z členství v Komunistické straně Československa, a to včetně dostupného rozlišení, zda byl respondent řadovým členem, či funkcionářem. ${ }^{8}$ Ekonomický kapitál je zachycen jako celkový př́ijem domácnosti respondenta přepočtený na počet členů domácnosti. ${ }^{9} \mathrm{Z}$ důvodu výrazně nižšího př́ijmu domácností důchodců byly

5 Vzhledem k obecným oborovým zvyklostem př́spěvků sociologie města či urban studies zde není čtenář zatěžován detailním popisem statistických procedur a výsledků jednotlivých post hoc testů, které byly provedeny u prezentovaných kontingenčních tabulek. Věŕím, že to přispívá k přehlednosti předkládaných zjištění. Podrobný přehled testování je samozřejmě na vyžádání k dispozici.

6 Datové soubory včetně potřebné dokumentace byly poskytnuty Českým sociálněvědním datovým archivem Sociologického ústav AV ČR, v.v.i., kterému na tomto místě také patří poděkování. Uvedené velikosti vzorků se vztahují na podsoubory, se kterými bylo pracováno v analýze (česká populace starší 18 let).

8 Je třeba upozornit, že měření kulturního a politického kapitálu je mimo jiné zkresleno nezahrnutím postavení partnerů respondenta. U politického kapitálu tato informace nebyla při šetření zjištována, u kulturního kapitálu byla vědomě opomenuta kvůli lepší srovnatelnosti obou typů kapitálu.

9 Počet členů domácnosti byl pro účely tohoto výpočtu modifikován obvyklou metodikou odrážející úspory z rozsahu u větších domácností. Kromě prvního člena domácnosti je každý další člen započítáván pouze s koeficientem 0,5 , každé dítě mladší 13 let pak s koeficientem 0,3. 
tyto domácnosti vyčleněny jako zvláštní kategorie,$^{10}$ ostatní domácnosti pak byly rozděleny na stejně velké prŕjimové kvartily.

Typ bydlení byl zachycen použitím jednoduché typologie vystihující hlavní odlišné způsoby bydlení v české společnosti (rodinné domky, starší zástavba a sídliště). ${ }^{11}$ Proměnná misto bydliště pak rozlišovala čtyři stupně - venkovská obec, malé město (do 10000 obyvatel), město (od 10000 do 150000 obyvatel) a velké město (nad 150000 obyvatel). Vlastnictví chaty bylo zjišt’ováno př́mou otázkou „máte chatu či rekreační chalupu?“ (odpovědi ano/ne).

Kromě těchto charakteristik, které prostupují celou analýzou, jsou v konkrétních výstupech použity další proměnné odrážející velikost a kvalitu bydlení, preference a spokojenost respondentů. Způsob operacionalizace těchto proměnných je uveden vždy na odpovídajícím místě analýzy.

Drobná poznámka na závěr - řadu empirických zjištění, která jsou zachycena v následující analýze, by jistě bylo možné identifikovat i v kontextu dnešní české společnosti. Přesto se při následujících popisech snažím důsledně držet historizujícího minulého času, aby čtenář nenabyl dojmu, že tyto závěry lze bez dalších analýz vztáhnout i na současnost. Zároveň tím ale nemá být řečeno, že popisované vztahy již v současnosti nutně nejsou relevantní.

\section{Sídelní struktura a sociální prostor}

Analýza distribuce forem bydlení a jejich sociálních významů v české společnosti pozdního socialismu se neobejde bez zasazení do kontextu sídelní struktury. ${ }^{12}$ Zásadní rozdíl mezi

10 Bez tohoto vyčlenění byly charakteristiky nejchudšího př́ijmového kvartilu výrazně ovlivněny převahou tohoto typu domácnosti. Tím by ale mohlo dojít k záměně významu generační prríslušnosti či etap životního cyklu s př́ijmem.

11 Šetření TSS 1984 rozlišovalo kategorie: „rodinný domek“ a „zemědělská usedlost“ (kat. rodinný domek); „menší bytový dům ve starší zástavbě (max. dvoupatrový)“ a „větší bytový dům ve starší zástavbě“ (kat. starší zástavba); a „sídliště“. Respondenti, kteří zvolili variantu ,jiný typ bydlení“ (2,8 \%), byli z analýzy vyřazeni. V šetření TSS 1984 - Postoje nebyla tato proměnná k dispozici. Obdobné rozdělení do tř́ typů bydlení bylo vytvořeno na základě kombinace otázek o prostředí bydliště („typické městské sídliště“ vs. ostatní kategorie) a disponování nemovitostí - „rodinný domek“. V případě šetření Životní prostředí Prahy 1977 byla tato typologie založena na kategoriích „nájemní vila nebo menší nájemní dům do 8 bytů“, ,,rodinný dům městského typu“a „,rodinný dům vesnického typu“ (kat. rodinný domek), „starší nájemní dům (nad 10 bytů)“ či „,starší nájemní dům do 10 bytů“ (kat. starší zástavba), „novější nájemní dům sídlištního typu“ (kat. sídliště).

12 Při studiu trhu s bydlením Bourdieu sleduje klasické ekonomické rozdělení mezi poptávkou a nabídkou, výrazně se ale od ekonomického modelu odlišuje tím, že obě strany tržní rovnice nechápe jako dané a nepodmíněné, ale naopak ukazuje, jakým zpo̊sobem jsou sociálně konstruovány (Bourdieu 2005: 15-17). To ale také znamená, že analýza, která by se zaměřovala pouze na vkus a preference v bydlení (poptávku), aniž by zohledňovala existující strukturu bytů a bytovou politiku (nabídku), by byla neúplná. Struktura forem bydlení je přitom silně diferencována podle sídelní velikosti a vzhledem k nízké míře migrace v české společnosti má proto smysl uvažovat o obcích různé velikosti jako o potenciálně odlišných symbolických trzích s bydlením. Jinak řečeno, zatímco ve venkovské obci je bydlení v rodinném domku naprostou samožrejmostí a prrípadné statusové vymezování zde bude spíše probíhat $\mathrm{v}$ diferenciaci odlišných podob této 
velkoměsty a menšími městy či venkovskými obcemi co do struktury bydlení (Tabulka 1), ale i předpokládaného významu, který je s těmito formami spojován, nutí rozdělit následující postup do dvou kroků. $\mathrm{V}$ první části se zaměřím na rozdíly mezi městem a venkovem a na souvislost akumulovaných kapitálů $\mathrm{s}$ individuálními migračními drahami z venkova do měst. Ve druhé části bude analýza zúžena na respondenty bydlící ve větších městech s více než 10000 obyvateli. V těchto městech lze již předpokládat podobnější strukturu bydlení, a tím i srovnatelnější významy spojené s analyzovanými kategoriemi.

Tabulka 1: Typ bydlení podle velikosti místa bydliště, 1984, řádková \%

\begin{tabular}{|l|c|c|c|}
\hline & rodinný domek & starší zástavba & sídliště \\
\hline velké město (více než 150 tis.) & 17 & 37 & 46 \\
\hline město (10-150 tis.) & 27 & 23 & 50 \\
\hline malé město (do 10 tis.) & 53 & 20 & 26 \\
\hline venkovské obce & 87 & 9 & 4 \\
\hline
\end{tabular}

Všechny rozdíly v tabulce jsou statisticky významné.

Data: TSS 1984, $\mathrm{N}=11713$

Volba místa bydliště není pouhým náhodným, na kapitálech nezávislým faktorem, ale přímo souvisí s diferenciací residenčních preferencí a dostupných zdrojů, která je založena na pozici jedince v sociálním prostoru. Velká města poskytují pracovní i volnočasové př́ležitosti především pro kvalifikované jedince, kteří si spíše osvojili dominantní kulturu. Města jsou také významným zdrojem symbolické moci, mimo jiné i tím, že koncentrují řadu institucí, jež se na definování kulturního kapitálu podílí. Geografický prostor tudíž není možné v bourdieuovské perspektivě považovat za sociálně neutrální (Bourdieu 1984: 102).

Individuální historie zachycené v dotazníkovém šetření odrážejí sílu urbanizačních procesů, které jsou s biografiemi v průběhu 20. století neodlučitelně spjaty (Tabulka 2). I když $62 \%$ respondentů bydlelo $\mathrm{v}$ roce $1984 \mathrm{v}$ obci stejné velikostní kategorie jako prri narození (polovina $\mathrm{z}$ nich prritom představovala stálé obyvatele venkovských obcí), tak dalších $30 \%$ se v průběhu života přestěhovalo do větší obce. Oproti tomu dezurbanizační mobilitou prošlo pouze necelých $10 \%$ respondentů.

Záměrem zde není podat komplexní popis migračních vzorců, kterými se z geografické perspektivy zabývala řada autorů jinde (např. Hampl a Kühnl 1993; Čermák 1996; Drbohlav 1990). Cílem je spíše poodkrýt, jakým způsobem tato mobilita bezprostředně souvisí se sociálním postavením, konkrétně jak s ní souvisí různé formy akumulovaných kapitálů. Vztah mezi prostorovou mobilitou a sociálním postavením lze pouze obtížně charakterizovat z hlediska příčinnosti. Např́iklad vyšší vzdělání může působit jako zdroj migrace, stejně jako stěhování do větších měst může rozšíriit př́iležitosti pro vzdělávání. Pro posouzení těchto vztahů

formy bydlení, pro obyvatele velkých měst se jedná o specifickou volbu, která je navázána na jiné významy než na venkově. Analýza, která neodděluje tyto lokálně odlišné „trhy“, se proto vystavuje riziku zanedbání významových rozdílů uvnitř sloučených kategorií. 
proto upřednostňuji základní bivariátní metody spíše než vícerozměrnou logistickou regresi, jejíž interpretace by mohla být vzhledem k obtížné identifikaci jednoznačných kauzalit zkreslující. Pro jednoduchost je také zanedbána možnost složitější residenční trajektorie, která by zahrnovala stěhování do měst a opětovné návraty na venkov. ${ }^{13}$

Tabulka 2: Velikost místa bydliště v současnosti a rodiště, 1984, celková \%

\begin{tabular}{|l|c|c|c|c|}
\hline & \multicolumn{4}{|c|}{ současné bydliště } \\
\hline rodiště & velké město & město & malé město & venkovské obce \\
\hline velké město & 12 & 2 & 1 & 1 \\
\hline město & 2 & 15 & 1 & 2 \\
\hline malé město & 2 & 3 & 5 & 2 \\
\hline venkovské obce & 5 & 12 & 5 & 30 \\
\hline
\end{tabular}

Data: TSS 1984, N = 11713

Výsledky jednoznačně poukazují na silné propojení mezi migrací z venkova do měst a dosaženým vzděláním (Tabulka 3). Sledujeme-li residenční trajektorii respondentů, kteří se narodili v menších obcích podle dosaženého vzdělání, vidíme, že zatímco ve velkých městech skončilo $70 \% \mathrm{z}$ těch, kteří dosáhli vysokoškolského vzdělání, tak v př́ípadě základního vzdělání se jedná pouze o $27 \%$. ${ }^{14}$ Ve srovnání s tímto silným vztahem se nezdá, že by ostatní formy kapitálu měly podobnou souvislost s migračními drahami. Členství v KSČ bylo častěji spojeno s přestěhováním do měst (47\%, resp. $41 \%$ u členů oproti $33 \%$ u nečlenů), ale zdaleka ne tak výrazně jako v případě dosaženého vzdělání.

Tabulka 3: Podíl migrujících z menších obcí do měst podle akumulovaného kapitálu (v \%), 1984

\begin{tabular}{|c|c|c|c|c|c|}
\hline \multicolumn{2}{c|}{$\begin{array}{c}\text { vzdělání } \\
\text { (kulturní kapitál) }\end{array}$} & \multicolumn{2}{c|}{$\begin{array}{c}\text { členství v ksč } \\
\text { (politický kapitál) }\end{array}$} & \multicolumn{2}{c|}{$\begin{array}{c}\text { príjem domácnosti } \\
\text { (ekonomický kapitál) }\end{array}$} \\
\hline základní & 27 & funkcionář & 47 & 1. kvartil & 34 \\
\hline střední bez maturity & 33 & člen & 41 & 2. kvartil & 35 \\
\hline střední s maturitou & 47 & nečlen & 33 & 3. kvartil & 35 \\
\hline vysokoškolské & 70 & & & 4. kvartil & 41 \\
\hline & & & & dưchodci & 31 \\
\hline
\end{tabular}

V každé kategorii je uveden podíl respondentů narozených na vesnici nebo v menším městě, kteří v době dotazování bydleli ve městě s více než 10000 obyvateli.

Označené bloky vyznačují kategorie, které se statisticky významně odlišují od ostatních (chí-kvadrát test).

Data: TSS 1984, N=7538

13 Jedná se přibližně o $6 \%$ z respondentů, kteří se narodili v malých městech či na vesnici.

14 Další analýzy, které nebyly z prostorových důvodů do textu zařazeny, přitom ukazují, že tento rozdíl nelze vysvětlit generačními rozdíly mezi respondenty. 
Uskutečněná migrace či naopak stabilita bydlení přitom může úzce souviset i s preferencemi bydlení. Aniž by bylo možné hovořit o příčinnosti, lze na základě dat konstatovat významné rozdíly v ochotě bydlet ve velkém městě (Tabulka 4). Zatímco dvě třetiny setrvalých obyvatel větších měst (64 \%) považují velké město za ideální k bydlení, mezi nově příchozími z menších obcí je to pouze $40 \%$ a u stabilních obyvatel menších obcí se jedná o zcela zanedbatelné množství (6 \%). ${ }^{15}$ Souvislost se současným a minulým místem bydliště u preference velkého města převyšuje vztah s kulturním kapitálem. I u něj můžeme ale rozpoznat určitou nezanedbatelnou vazbu. Lidé s vyšším vzděláním v každé kategorii migrační historie vyjadřovali vyšší preferenci bydlení ve velkém městě než ostatní.

Tabulka 4: Podíl obyvatel, kteří by chtěli bydlet ve větším městě podle dosaženého vzdělání a migrační historie (v \%), 1984

\begin{tabular}{|l|c|c|c|c|}
\hline \multirow{2}{*}{} & \multirow{2}{*}{ celkem } & migrační historie \\
\cline { 2 - 5 } & 23 & pouze menší obce & $\begin{array}{c}\text { z menších obcí } \\
\text { do větších měst }\end{array}$ & pouze větší města \\
\hline základní & 33 & 4 & 36 & 55 \\
\hline střední bez maturity & 45 & 5 & 40 & 64 \\
\hline střední s maturitou & 53 & 11 & 41 & 68 \\
\hline vysokoškolské & 34 & 18 & 44 & 74 \\
\hline celkem & & 6 & 40 & 64 \\
\hline
\end{tabular}

Rozdíly v preferenci bydlení mezi jednotlivými variantami migrační historie jsou statisticky významné, a to i v rámci jednotlivých vzdělanostních kategorií. Rozdíly v preferenci bydlení mezi jednotlivými kategoriemi vzdělání jsou statisticky významné v celkovém pohledu. V rámci jednotlivých migračních drah jsou rozdíly statisticky významné pouze mezi extrémními hodnotami obyvatel ,pouze menších obcí“a ,ppouze větších měst“”.

Data: TSS 1984 Postoje, $\mathrm{N}=2084$

Použijeme-li Bourdieuho koncept pole jako nástroje pro analýzu sociálních vztahů, můžeme uvažovat o tom, že velká města představují jakési „magnetické póly“ kulturního kapitálu. Kulturní kapitál je v nich koncentrován, produkován a definován prostřednictvím klíčových dominantních aktérů (vysoké školy, média, kulturní instituce apod.). Přesun jedinců, kteří pocházejí z „odlehlých“ oblastí sociálního prostoru, do těchto center bývá přitom spojen s akumulací kulturního kapitálu (viz Tabulka 3), stejně jako nositele tohoto kapitálu velká města v určité míře více přitahují (viz Tabulka 4).

15 Migrační historie byla zkonstruována na základě současného místa bydliště (větší a stř̌ední města / menší města a vesnice) a toho, zda respondent uvedl, že alespoň 5 let žil na venkově či v menším městě (údaje o místu rodiště nebyly v tomto datovém souboru dostupné). Vychází tedy z předpokladu převažující urbanizační tendence a zanedbatelného dezurbanizačního proudu. Zastoupení jednotlivých kategorií této klasifikace ve výsledku odpovídá datům v tabulce 2 . 


\section{Město a formy bydlení}

Následující část analýzy je již výhradně zaměřena na obyvatele středních a velkých měst. Tento stejnorodější kontext umožňuje jednak snižit riziko směšování významově odlišných forem bydlení ve městě a na venkově a také jednoznačněji popsat vztah mezi kulturním kapitálem, podobou a preferencemi bydlení v urbánním prostředí.

Zatímco stěhování do měst bylo silně spjato s kulturním kapitálem, tak umístění obyvatel ve struktuře města na něm bylo relativně nezávislé. Vztah mezi vzděláním a typem bydlení byl velice slabý (Tabulka 4), projevuje se pouze v nižší šanci respondentů se základním vzděláním bydlet na panelových sídlištích. Obdobně slabý strukturující efekt měl i politický kapitál, kde se ukazuje, že členství v KSČ bylo spojeno s častějším bydlením na sídlištích. Př́ijem domácnosti u ekonomicky aktivních pak s typem bydlení nesouvisí, pouze domácnosti důchodců méně často bydlely na sídlištích. Tento rozdíl lze ale vysvětlit spíše odlišnou věkovou strukturou srovnávaných skupin než jejich ekonomickým postavením.

Významným způsobem ale bylo s pozicí v sociálním prostoru spojeno vlastnictví chaty či chalupy. Zatímco chatou či chalupou disponovalo pouze $12 \%$ obyvatel měst se základním vzděláním, mezi vysokoškoláky byl podíl téměř třikrát vyšši (35\%). Obdobně vlastnilo chatu $30 \%$ domácností funkcionár̊u KSČ a 31 \% domácností z nejbohatšího př́ijmového kvartilu. Srovnání těchto faktorů nám může přinést výsledek binární logistické analýzy (Tabulka 5). ${ }^{16}$ Zde se ukazuje, že klíčovou dimenzí byl především kulturní kapitál. Respondenti s vysokoškolským vzděláním měli více než třikrát vyšši šanci, že budou vlastnit chatu, než respondenti se základním vzděláním. Oproti tomu členství v KSČ ani příjem domácnosti při kontrole ostatních proměnných tuto šanci neovlivňovaly. Chataření také představovalo určitou alternativu $\mathrm{k}$ bydlení v rodinném domku. Nejen obyvatelé panelových sídlišst', ale zejména ti ze staré zástavby měli výrazně vyšší šanci, že budou vlastnit chatu (dvakrát, resp. 2,4krát) než lidé bydlící v rodinném domku. Pro úplnost dodejme, že šanci vlastnit chatu významně zvyšovalo, pokud respondenti patřili do věkové kategorie 45-59 let (1,9krát) či pokud byli obyvatelé Prahy (1,8krát).

I když se ukázalo, že distribuce forem bydlení byla ve městech z hlediska jednotlivých kapitálů $\mathrm{v}$ zásadě rovnoměrná, subtilnější projevy nerovností je možné odhalit $\mathrm{v}$ dimenzích kvality bydlení. Szelényiho (1983) analýza mechanismů vzniku nerovností v socialistických společnostech se zaměřovala především na distribuci nově vznikajícího bytového fondu. Kromě toho, že koncentrace nové výstavby ve větších městech byla zdrojem rozdílů $\mathrm{v}$ dostupném subvencovaném bydlení mezi městem a venkovem, můžeme také sledovat, jaké rozdíly panovaly $\mathrm{v}$ přidělování bytů různé kvality. Zaměříme-li se výhradně na nové sídlištní byty postavené ve větších městech po roce 1960 přidělené respondentům městem či podnikem, př́padně subvencované skrze družstevní výstavbu, je patrné, že s rostoucím vzděláním roste i pravděpodobnost, že respondent bude bydlet v bytě s větší dispozicí (Tabulka 6). Zatímco mezi vysokoškoláky v této skupině respondentů je $12 \%$ obyvatel bytů $4+1$ a $55 \%$ obyvatel bytů $3+1$, u respondentů se základním vzděláním se jedná pouze o $6 \%$, respektive $40 \%$. Tento rozdíl přetrvává, i když analýzu omezíme v souladu s tehdejšími kritérii pro přidělování bytů na nejčastější typ rodinných domácností dvou rodičů se dvěma nezletilými

16 Kromě uvedených tří kapitálů do logistické regresní analýzy vstupovaly proměnné: věk (4 kategorie), dítě v domácnosti (ano/ne) a Praha jako místo bydliště (Praha / jiné velké město). 
dětmi. Oproti dosaženému vzdělání nebyl rozpoznán vliv členství v KSČ či přijmu domácnosti na takto měřenou kvalitu bydlení.

Tabulka 5: Typ bydlení podle úrovně kulturního kapitálu (vzdělání), obyvatelé větších měst, 1984, řádková \%

\begin{tabular}{|l|c|c|c|c|}
\hline vzdělání & rodinný domek & starší zástavba & sídliště & $\begin{array}{c}\text { podíl domácností } \\
\text { s chatou (v \%) }\end{array}$ \\
\hline základní & 27 & 34 & 39 & 12 \\
\hline střední bez maturity & 23 & 28 & 49 & 20 \\
\hline střední s maturitou & 23 & 25 & 53 & 27 \\
\hline vysokoškolské & 19 & 28 & 53 & 35 \\
\hline & & & & \\
\hline členství v KSč & & & 59 & 30 \\
\hline člen funkcionář & 19 & 22 & 54 & 19 \\
\hline člen bez funkce & 21 & 25 & 47 & 21 \\
\hline nečlen & 24 & 30 & & 15 \\
\hline & & & 53 & 22 \\
\hline př́jem domácnosti & & 27 & 56 & 23 \\
\hline 1. kvartil & 20 & 23 & 55 & 31 \\
\hline 2. kvartil & 22 & 24 & 50 & 16 \\
\hline 3. kvartil & 21 & 27 & 29 & 14 \\
\hline 4. kvartil & 22 & 41 & 30 & \\
\hline důchodci & 31 & 21 & & \\
\hline & 49 & & & \\
\hline Celkem & & & & \\
\hline
\end{tabular}

Označené bloky vyznačují kategorie, které se statisticky významně odlišují od ostatních (chí-kvadrát test). Data: TSS 1984, $\mathrm{N}=6247$

Výzkum pražského obyvatelstva z roku 1977 podrobněji ukazuje, že lidé s vyšším vzděláním bydleli v bytech vyšší kvality i z hlediska jiných parametrů. Zatímco 57 \% vysokoškoláků bydlelo $\mathrm{v}$ bytech 1 . kategorie, $\mathrm{v}$ případě osob se základním vzděláním se jednalo pouze o $25 \%$. Podobně na jednu osobu v domácnosti vysokoškoláka připadalo necelých $17 \mathrm{~m}^{2}$, zatímco u lidí se základním vzděláním to bylo pouze $14 \mathrm{~m}^{2}$. Telefon zavedený do bytu, což v této době nebylo samozřjmostí, mělo 81 \% vysokoškoláku, ale pouze polovina lidí se základním vzděláním. ${ }^{17}$ Tyto rozdíly není možné srovnat s obdobným tř́děním podle politického či kulturního kapitálu, protože výzkum z roku 1977 tyto proměnné nezahrnuje.

17 Z prostorových důvodů neuvedené podrobnější analýzy ukazují, že kvalitnějšího bydlení dosahovaly lépe vzdělané domácnosti i v rámci jednotlivých typů bydlení. Např́iklad zatímco ve staré zástavbě bydlelo pouze $12 \%$ obyvatel bez maturity v bytech 1 . kategorie, mezi vysokoškoláky to bylo více než $30 \%$. 
Tabulka 6: Faktory ovlivňující vlastnictví chaty, binární logistická regrese, obyvatelé větších měst, 1984

\begin{tabular}{|c|c|c|c|}
\hline & B & $\exp (B)$ & sig. \\
\hline \multicolumn{4}{|l|}{ věk } \\
\hline $30-44$ & 0,13 & 1,14 & 0,17 \\
\hline $45-59$ & 0,62 & 1,86 & $<0,01$ \\
\hline $60+$ & $-0,21$ & 0,81 & 0,15 \\
\hline dítě v domácnosti & $-0,21$ & 0,81 & 0,02 \\
\hline \multicolumn{4}{|l|}{ vzdělání } \\
\hline střední bez maturity & 0,59 & 1,80 & $<0,01$ \\
\hline střední s maturitou & 0,98 & 2,65 & $<0,01$ \\
\hline vysokoškolské & 1,20 & 3,32 & $<0,01$ \\
\hline \multicolumn{4}{|l|}{ členství ve straně } \\
\hline člen & 0,12 & 1,13 & 0,29 \\
\hline funkcionář & $-0,18$ & 0,83 & 0,09 \\
\hline \multicolumn{4}{|l|}{ príijem } \\
\hline 2. kvartil & $-0,34$ & 0,71 & 0,02 \\
\hline 3. kvartil & 0,08 & 1,08 & 0,58 \\
\hline 4. kvartil & $-0,01$ & 0,99 & 0,95 \\
\hline důchodci & 0,21 & 1,23 & 0,11 \\
\hline Praha & 0,56 & 1,75 & $<0,01$ \\
\hline \multicolumn{4}{|l|}{ typ bydlení } \\
\hline stará zástavba & 0,88 & 2,41 & $<0,01$ \\
\hline sídliště & 0,71 & 2,03 & $<0,01$ \\
\hline konstanta & $-2,80$ & 0,06 & $<0,01$ \\
\hline Nagelkerkeho $r^{2}$ & 0,122 & & \\
\hline
\end{tabular}

Ref. skupiny: věk - „18-29“; vzdělání - „základní“; členství ve straně - „nečlen“; příjem - „1. kvartil“; typ bydlení - „rodinný domek“

Data: TSS 1984, N = 6274

Tabulka 7: Velikost přidělených sídlištních bytů podle úrovně kulturního kapitálu (vzdělání), obyvatelé větších měst, 1984, řádková \%

\begin{tabular}{|l|l|l|l|l|l|}
\hline & & & & \multicolumn{3}{|c|}{$\begin{array}{l}\text { pouze rodinné domácnosti } \\
(\mathbf{2}+\mathbf{2} \text { děti) }\end{array}$} \\
\hline & do $\mathbf{2 + 1}$ & $\mathbf{3 + 1}$ & $\mathbf{4 + 1}$ a větší & do $\mathbf{2 + 1}$ & $\mathbf{3 + 1}$ a větší \\
\hline základní & 55 & 40 & 6 & 34 & 66 \\
\hline střední bez maturity & 46 & 47 & 7 & 28 & 72 \\
\hline střední s maturitou & 37 & 54 & 9 & 17 & 83 \\
\hline vysokoškolské & 33 & 55 & 12 & 13 & 87 \\
\hline
\end{tabular}

Označené bloky vyznačují kategorie, které se statisticky významně odlišují od ostatních (chí-kvadrát test).

Data: TSS 1984, N = 2294 
Tabulka 8: Charakteristiky kvality bydlení podle úrovně kulturního kapitálu (vzdělání), Praha, 1977

\begin{tabular}{|l|c|c|c|}
\hline & byt 1. kategorie (v \%) & $\mathbf{m}^{2}$ plochy / osob v bytě & telefon v domácnosti (v \%) \\
\hline základní & 25 & 14,1 & 50 \\
\hline střední bez maturity & 32 & 14,3 & 53 \\
\hline střední s maturitou & 43 & 15,8 & 74 \\
\hline vysokoškolské & 57 & 16,9 & 81 \\
\hline
\end{tabular}

Označené bloky vyznačují kategorie, které se statisticky významně odlišují od ostatních (ANOVA a chí-kvadrát test). Data: Životní prostředí Prahy 1977, N = 1983

Podobně jako v př́padě rozdílu ve struktuře bydlení se i v oblasti preferencí u obyvatel větších měst projevil pouze velice slabý vztah mezi sociálním prostorem a diferenciací upřednostňovaných forem bydlení. Bez ohledu na objem kulturního, politického či ekonomického kapitálu o něco více než polovina obyvatel větších měst nebydlela a ani nechtěla bydlet v rodinném domě (Tabulka 9). ${ }^{18}$

Jediným významněji diferencovaným prvkem mezi sledovanými byla chut' či nechut' mít chatu. Zatímco mezi obyvateli velkých měst se základním vzděláním téměř tři čtvrtiny (73 \%) nemělo či nechtělo chatu, mezi vysokoškoláky to byla pouze o něco více než polovina $(51 \%)$. Tento rozdíl lze částečně přičíst většímu rozšírení vlastnictví chaty mezi vzdělanějšími respondenty, ale stejně tak i tomu, že vzdělanější respondenti bez chaty ji postrádali častěji než ti ostatní.

Rozdílné vnímání tradiční městské zástavby a panelových sídlišst je možné zachytit u obyvatel Prahy prostřednictvím šetření z roku 1977. Předem je potřeba upozornit na to, že otázka byla v dotazníku formulována tak, že respondent měl zvolit právě mezi těmito dvěma alternativami městského bydlení, a zároveň bylo při položení dotazu prímo uvedeno, že by se jednalo o hypotetickou volbu mezi dvěma byty stejné kvality, pouze v odlišném prostředí. Přitom je nutné konstatovat, že to byla právě kvalita bytů, která v této době zásadně odlišovala oba typy zástavby a která také mohla výrazně ovlivňovat reálné rozhodování a spokojenost $\mathrm{s}$ bydlením.

Z výstupu šetření je patrná výrazná dominance tradiční zástavby nad sídlištními byty (Tabulka 10, $61 \%$ oproti $27 \%$ ). Dosažené vzdělání přitom s preferencemi bydlení nesouvisí, poměr upřednostnění obou typů bydlení je u všech vzdělanostních kategorií stejný. Výraznější souvislost se objevuje pouze v případě skutečné podoby bydlení, ve které respondenti bydlí. Poměr preferencí se zcela obrací u obyvatel sídlišt', kteří by volili sídliště v 59 \% a starou zástavbu v 31 \% př́padů. Naopak u obyvatel starší zástavby se upřednostnění tohoto typu bydlení ještě více vyhrocuje a dosahuje $73 \%$ (oproti $15 \%$, kteří by volili sídliště). Při posuzování vztahu skutečného a preferovaného bydlení je třeba upozornit na jeho

18 Přesněji řečeno, tito respondenti uvedli, že rodinný dům ,nemají a nevadí jim to“, oproti tomu, že ho „nemají a postrádají ho“. Tento náhled lze doplnit další z otázek, podle které je pro 54 \% obyvatel velkých měst možnost bydlet v rodinném domku při volbě místa bydliště „spíše nedůležitá“ nebo „vůbec není důležitá“. 
obousměrnost. Lidé preferující určitý typ bydlení mohli vlastní aktivitou přispět k jeho získání i v realitně rigidnějším socialistickém trhu s byty. Zároveň ale také mohla reálná zkušenost $\mathrm{s}$ bydlením, které bývalo $\mathrm{v}$ populaci a priori vnímáno jako anonymní a dehumanizované (srov. Musil a kol. 1985), tuto představu proměnit.

V této souvislosti je podstatným zjištěním, že kromě obecně vyšší spokojenosti s vlastním bydlením u vysokoškolsky vzdělaných skupin deklarovali vysokou spokojenost také obyvatelé panelových sídlišt'. Úroveň jejich spokojenosti byla přibližně stejná jako u obyvatel rodinných domků a dalece přesahovala spokojenost s bydlením mezi obyvateli staré zástavby. Tento rozdíl naznačuje, že předcházející hypotetická otázka o preferencích typů zástavby mohla být výrazně ovlivněna právě explicitním předpokladem vyrovnané kvality bytů. Ve skutečnosti přitom $\mathrm{v}$ tehdejší době dosahovaly sídlištní byty výrazně vyššího standardu než nedostatečně udržované a zastarávající bydlení ve staré zástavbě.

Tabulka 9: Preference v bydlení obyvatel větších měst podle objemu kapitálů (v \%), 1984

\begin{tabular}{|l|c|c|}
\hline & \multicolumn{2}{|c|}{ nemá a nechce } \\
\hline vzdělání & dům & chatu \\
\hline základní & 51 & 73 \\
\hline střední bez maturity & 53 & 61 \\
\hline střední s maturitou & 57 & 48 \\
\hline vysokoškolské & 56 & 51 \\
\hline & & 56 \\
\hline členství v KSč & & 57 \\
\hline funkcionár̆ & 63 & 60 \\
\hline člen & 55 & 57 \\
\hline nečlen & 53 & 58 \\
\hline & & 55 \\
\hline př́jem & & 54 \\
\hline 1. kvartil & 52 & 72 \\
\hline 2. kvartil & 47 & \\
\hline 3. kvartil & 57 & 59 \\
\hline 4. kvartil & 54 & \\
\hline důchodci & 59 & \\
\hline & & \\
\hline Celkem & 54 & \\
\hline
\end{tabular}

Označené bloky vyznačují kategorie, které se statisticky významně odlišují od ostatních (chí-kvadrát test).

Data: TSS 1984 Postoje, $N=1227$ 
Tabulka 10: Preference v bydlení a spokojenost s bydlením obyvatel Prahy podle kulturního kapitálu a místa bydliště, 1977

\begin{tabular}{|l|c|c|c|}
\hline & \multicolumn{2}{|c|}{ preferované bydlenía } & \multirow{2}{*}{$\begin{array}{c}\text { spokojenost } \\
\text { s bydlením }\end{array}$} \\
\hline vzdělání & tradiční zástavba & sídliště & 3,46 \\
\hline základní & 63 & 25 & 3,47 \\
\hline střední bez maturity & 59 & 26 & 3,60 \\
\hline střední s maturitou & 62 & 28 & 3,81 \\
\hline vysokoškolské & 59 & 26 & \\
\hline & & & \\
\hline typ bydlení & & 23 & 3,89 \\
\hline rodinný domek & 57 & 15 & 3,29 \\
\hline starší zástavba & 73 & 59 & 3,97 \\
\hline sídliště & 31 & & \\
\hline & & 27 & 3,56 \\
\hline Celkem & 61 & & \\
\hline
\end{tabular}

a - Pokud by respondent mohl volit mezi bytem na sídlišti a stejně kvalitním bytem v tradiční (blokové) městské zástavbě, kterému by dal přednost. Přibližně $13 \%$ respondentů neví, jak by se rozhodlo, nebo by jim to bylo jedno. b - „Zamyslíte-li se nad svým bytem, jeho umístěním v domě i prostředím bydliště, jste s ním: velmi spokojen / spokojen / tak napůl / spíše nespokojen / velmi nespokojen. Numerická škála 1 - velmi nespokojen; 5 - velmi spokojen. Označené bloky vyznačují kategorie, které se statisticky významně odlišují od ostatních (ANOVA a chí-kvadrát test). $\mathrm{N}=1979$

\section{Diskuze}

Bydlení v české pozdně socialistické společnosti se ukazuje jako prostor různorodých a nejednoznačných projevů sociálních nerovností. Na jedné straně lze konstatovat nebývale stejnorodou distribuci jednotlivých forem bydlení ve velkých městech. Domácnosti s různým objemem kulturního, politického i ekonomického kapitálu bydlely stejně často v rodinných domcích, staré zástavbě i na nových sídlištích. Na druhé straně byla samotná mobilita do velkých měst významně spojena s akumulací kulturního kapitálu a zároveň lidé s vyšším kulturním kapitálem dosáhli ve městech na kvalitnější byty bez ohledu na typ zástavby, ve které bydleli. Přestože tedy například míra třídních nerovností v nově vystavěných sídlištích nedosahovala ke konci socialistické éry takové úrovně, jakou zaznamenával Szelényi (1983) na přelomu 60. a 70. let, nebyl vztah mezi sociálním prostorem a bydlením zcela zanedbatelný.

Podobný obraz dostáváme i při pohledu na rozdílné preference v oblasti bydlení. Opět zde můžeme rozpoznat zásadní rozdíly mezi městem a venkovem, které úzce sledují odlišnou strukturu bydlení $\mathrm{v}$ těchto typech prostoru. Obyvatelé velkých měst chápou rodinný domek jako daleko méně hodnotný a zároveň spíše preferují bydlení ve městě. Zároveň se ale navzdory očekávání neprojevilo, že by rozdíly v preferencích městských obyvatel souvisely 
s objemem jejich kapitálů. Upřednostňování individuálních rodinných domků, staré zástavby či panelových sídlišt’ se neukázalo významně stratifikované.

Samotná propojenost kulturního kapitálu a rozdílu mezi městem a venkovem představuje empiricky banální, ale konceptuálně podceňovaný vztah. Nerovné pozice spojené s odlišnou distribucí kulturního kapitálu se takto promítají do fyzického prostoru, kde jsou následně chápány jako přirozené (jsou naturalizovány), samozřejmé a neproblematické (Savage 2012). Státní subvence bytové výstavby směřovaly zejména do velkých měst, zatímco rodinné domky, které byly převažujícím a v lokálním kontextu venkova jediným akceptovaným způsobem bydlení, byly stavěny rodinami pomocí vlastních ekonomických, sociálních a časových zdrojů. Vstup do města přitom úzce souvisel s kulturním kapitálem, a to nejen jako oprávnění $\mathrm{k}$ městským pracovním př́ležitostem, ale také skrze s ním spojený habitus. Obyvatelé venkovských obcí, zejména pak ti bez kulturního kapitálu, nepovažovali město za vhodné místo k bydlení. Slovy Bourdieuho bychom zde mohli hovořit o jejich odmítání města jako o skutečném osvojení vkusu nezbytnosti (Bourdieu 1984: 372-396).

Jako další fenomén vhodný pro analýzu založenou na bourdieuovském přístupu se ukázalo chataření a chalupaření. Librová (1975) upozorňuje na výraznější zastoupení vzdělanějších vrstev mezi chalupáři a popisuje tehdejší praktiky, které by z pohledu symbolického vymezování mohly být efektivním prostředkem distinkce. ${ }^{19}$ Přestože zde představená analýza nemohla rekonstruovat klíčový rozdíl mezi chataři a chalupári, tak jak je v práci Librové popsán, lze i tak souhrnně konstatovat, že chataření/chalupaření bylo výrazně rozšiřrenější mezi vzdělanějšími vrstvami. Lidé s vyšším vzděláním častěji patřili mezi vlastníky chaty či chalupy, a pokud mezi ně nepatřili, tak je častěji chtěli. Představená analýza tak naznačuje možný směr dalšího studia, které by zachytilo nejen hrubé rysy tohoto fenoménu, ale kvalitativním způsobem by rozkrylo i odlišné významy a praktiky, které mohly, a stále mohou, být prostředkem distinkce. Na rozdíl od limitovaných možností projevů vkusu ve volbě a úpravách vlastního bydlení mohly být chaty a chalupy tvárnějším objektem vyjádření habitu.

V kontextu postsocialistického rozvoje suburbanizace zůstává zajímavou otázkou to, nakolik byla preference individualizovaného předměstského bydlení rozšířena i v socialistické společnosti a pouze kvůli nastavení bytové politiky nedocházela naplnění, nebo zda se rozvinula až s širrením nové sady spotřebních praktik bydlení po roce 1989. Jak již bylo řečeno, rodinný domek zdaleka nebyl nepreferovanou formou bydlení. Zároveň ale nenaplnění této preference nebylo pocit’ováno jako problém. Lidé na panelových sídlištích nevyjadřovali větší nespokojenost $\mathrm{s}$ vlastním bydlením než obyvatelé rodinných domků (srov. Tabulka 10), zároveň ani ti lépe postavení nevyjadřovali větší touhu po tomto typu bydlení než ti ostatní (srov. Tabulka 9). Obecně je vlastně otázka, zda je takto možné izolovat jednotlivé aspekty preferencí v podobě ideálního typu bydlení, popřípadě jeho velikosti, vybavení či ideální lokality. Povědomí o reálné struktuře trhu bydlení, ve které jsou tyto aspekty vždy provázány $\mathrm{v}$ určité konstelaci, způsobuje, že se takto zaměřené otázky stávají pouze umělým konstruktem. Řekneme-li, že někdo preferuje bydlení v rodinném domku, je otázkou, zda př́mo vyhledává tento typ architektonického řešení bytu, nebo oceňuje možnosti osobního

19 Např. konzervování tradiční architektury u nových majitelů chalup, pěstování komunitních vztahů, manuální práce jako forma odpočinku od města. 
vlastnictví a soukromí, které jsou s tímto typem bydlení spojeny (srov. Galčanová 2013), či zda se jedná o projev dominantní a do značné míry jediné možné normy bydlení v menších obcích. Změna politiky bydlení a trhu s bydlením přitom přináší proměny vzájemných vazeb mezi různými aspekty bydlení. Sídliště přestává být synonymem kvalitního standardu bydlení, rodinný dům zase výrazem vlastní manuální práce. V této perspektivě je pak předpoklad ekonomických analýz, že preference existují a priori a neodráží se v nich situace na straně nabídky, ze sociologického pohledu obtížně udržitelný.

\section{Literatura}

ANDRLE, Vladimír. Nepotopitelná třída: Rodinné zázemí v sebeprezentaci českých postkomunistických podnikatelů. Biograf, 1999, č. 18-19, s. 41-60. ISSN 1211-5770.

BARVÍKOVÁ, Jana. Jak se žije na Jižním Městě z pohledu „Husákových dětí“. Sociální studia, 2010, roč. 7, č. 3, s. 59-78. ISSN 1214-813X.

BENNETT, Tony a kol. Culture, Class, Distinction. London: Routledge, 2009. ISBN 9780203930571.

BLUNT, Alison a Robyn DOWLING. Home. London: Routledge, 2006. ISBN 978-0415332743.

BODNÁR, Judit a József BÖRÖCZ. Housing advantages for the better connected? Institutional segmentation, settlement type and social network effects in Hungary's late state-socialist housing inequalities. Social forces, 1998, roč. 76, č. 4, s. 1275-1304. ISSN 0037-7732.

BOTERMAN, Willem R. Deconstructing Coincidence: How Middle-Class Households Use Various Forms of Capital to Find a Home. Housing, Theory and Society, 2012, roč. 29, č. 3, s. 321-338. ISSN 1403-6096.

BOTTERO, Wendy. Stratification: Social Division and Inequality. London: Routledge, 2005. ISBN $0-415-28179-2$.

BOURDIEU, Pierre. Distinction: A Social Critique of the Judgement of Taste. Cambridge: Harvard University Press, 1984. ISBN 0-674-21277-0.

BOURDIEU, Pierre. „Sovětská“ varianta a politický kapitál. In BOURDIEU, Pierre. Teorie jednání. Praha: Karolinum, 1998, s. 21-25. ISBN 80-7184-518-3.

BOURDIEU, Pierre. The Social Structures of the Economy. Cambridge: Polity Press, 2005. ISBN 978-0745625393.

BREIGER, Ronald L. A tool kit for practice theory. Poetics, 2000, roč. 27, č. 2-3, s. 91-115. ISSN 0304-422X.

BREN, Paulina. Weekend Getaways: The Chata, the Tramp and the Politics of Private Life in Post-1968 Czechoslovakia. In CROWLEY, David a Susan E. REID (eds.). Socialist Spaces: Sites of Everyday Life in the Eastern Bloc. Oxford: Berg, 2002, s. 123-140. ISBN 978-1859735381.

BRIDGE, Gary. Estate Agents as Interpreters of Economic and Cultural Capital: The Gentrification Premium in the Sydney Housing Market. International Journal of Urban and Regional Research, 2001, roč. 25, č. 1, s. 87-101. ISSN 1468-2427.

BRIDGE, Gary. It's Not Just a Question of Taste: Gentrification, the Neighbourhood, and Cultural Capital. Environment and Planning A, 2006a, roč. 38, č. 10, s. 1965-1978. ISSN 0308-518X.

BRIDGE, Gary. Perspectives on cultural capital and the neighbourhood. Urban Studies, 2006b, roč. 43, č. 4, s. 719-730. ISSN 0042-0980.

ČERMÁK, Zdeněk. Internal Migration in the Czech Republic During Period of Transition. Acta Facultatis Rerum Naturalium Universitatis Comenianae, 1996, č. 37, s. 122-130. ISBN 80-223-1042-5.

DRBOHLAV, Dušan. Důvody regionálních a sídelních preferencí obyvatelstva ČR. Sborník Československé geografické společnosti, 1990, roč. 95, č. 1, s. 13-29. ISSN 1212-0014. 
EYAL, Gil, Iván SZELÉNYI a Eleanor TOWNSLEY. Making Capitalism Without Capitalists: Class Formation and Elite Struggles in Post-Communist Central Europe. London: Verso, 1998. ISBN 78-1859843123.

FERENČUHOVÁ, Slavomíra a Mark JAYNE. Zvyknút' si na Petržalku: každodenný život, bežná spotreba a vzt’ah k socialistickému sídlisku. Český lid, 2013, roč. 100, č. 3, s. 303-318. ISSN 0009-0794.

GALČANOVÁ, Lucie. Svoboda, soukromí a bezpečí: nové hraniční prostory v naracích obyvatel vybraných brněnských předměstí. In OUŘEDNÍČEK, Martin, Petra ŠPAČKOVÁ a Jakub NOVÁK (eds.). Sub Urbs: krajina, sídla a lidé. Praha: Academia, 2013, s. 200-233. ISBN 978-80-200-2226-4.

GRAM-HANSSEN, Kirsten a Claus BECH-DANIELSEN. House, Home and Identity from a Consumption Perspective. Housing, Theory and Society, 2004, roč. 21, č. 1, s. 17-26. ISSN 1403-6096.

HAMPL, Martin a Karel KÜHNL. Migratory trends in former Czechoslovakia. Acta Universitatis Carolinae Geographica, 1993, č. 1, s. 53-71. ISSN 0300-5402.

KOSTELECKÝ, Tomáš. Postoje obyvatel k situaci na trhu s bydlením a bytové politice: existují v České republice „housing classes“? Sociologický časopis, 2005, roč. 41, č. 2, s. 253-270. ISSN 0038-0288.

KREIDL, Martin. Cesty ke vzdělání: vzdělanostní dráhy a vzdělanostni nerovnosti v socialismu. Plzeň: Západočeská univerzita v Plzni, 2008. ISBN 978-80-7043-678-3.

LE ROUX, Brigitte a Henry ROUANET. Geometric Data Analysis: From Correspondence Analysis to Structured Data Analysis. Dordrecht: Kluwer Academic Publishers, 2004. ISBN 978-1-4020-2236-4.

LIBROVÁ, Hana. Dva typy druhého bydlení v ČSR. Sborník praci Filozofické fakulty brněnské univerzity, 1975, roč. 24, č. G19, s. 53-64.

LUX, Martin a Tomáš KOSTELECKÝ (eds.). Bytová politika: teorie a inovace pro praxi. Praha: Sociologické nakladatelství, 2011. ISBN 978-80-7419-068-1.

LUX, Martin, Petr SUNEGA a Tomáš KATRŇÁK. Classes and Castles: Impact of Social Stratification on Housing Inequality in Post-Socialist States. European Sociological Review, 2013, roč. 29, č. 2, s. 274-288. ISSN 0038-0288.

MATĚJŮ, Petr, Jiří VEČERNÍK a Hynek JEŘÁBEK. Social structure, spatial structure and problems of urban research: the example of Prague. International Journal of Urban and Regional Research, 1979, roč. 3, č. 2, s. 181-202. ISSN 1468-2427.

MONEY, Annemarie. Material Culture and the Living Room: The Appropriation and Use of Goods in Everyday Life. Journal of Consumer Culture, 2007, roč. 7, č. 3, s. 355-377. ISSN 1469-5405.

MOŽNÝ, Ivo. Proč tak snadno...: Některé rodinné di̊vody sametové revoluce. Praha: Sociologické nakladatelství, 1999. ISBN 80-85850-80-X.

MUSIL, Jiří. Housing policy and the sociospatial structure of cities in a socialist country: the example of Prague. International Journal of Urban \& Regional Research, 1987, roč. 11, č. 1, s. 27-36. ISSN 1468-2427.

MUSIL, Jiří. Nové vymezení sociální ekologie. Sociologický časopis, 1991, roč. 27, č. 1, s. 69-89. ISSN 0038-0288.

MUSIL, Jiří. Urbanizace českých zemí a socialismus. In HORSKÁ, Pavla, Eduard MAUR a Jiří MUSIL (eds.). Zrod velkoměsta: Urbanizace českých zemí a Evropa. Praha: Paseka, 2002, s. 237-297. ISBN 80-7185-409-3.

MUSIL, Jiří. Proměny urbánní sociologie ve Spojených státech a Evropě 1950-2000. Sociologický časopis, 2003, roč. 39, č. 2, s. 137-167. ISSN 0038-0288.

MUSIL, Jiří a kol. Lidé a sidliště. Praha: Svoboda, 1985.

SAVAGE, Mike. The Lost Urban Sociology of Pierre Bourdieu. In BRIDGE, Gary a Sophie WATSON (eds.). The New Blackwell Companion to the City. Oxford: Wiley-Blackwell, 2012, s. 511-520. ISBN 978-1-4051-8981-1.

SAVAGE, Mike a kol. Focus Article. Housing, Theory and Society, 2010, roč. 27, č. 2, s. 115-161. ISSN 1403-6096. 
SILVA, Elizabeth B. a David WRIGHT. Displaying Desire and Distinction in Housing. Cultural Sociology, 2009, roč. 3, č. 1, s. 31-50. ISSN 1749-9755.

SMITH, David M. The Socialist City. In ANDRUSZ Gregory, Michael HARLOE a Ivan SZELENYI (eds.). Cities after Socialism: Urban and Regional Change and Conflict in Post-Socialist Societies. Oxford: Blackwell, 1996, s. 70-99. ISBN 978-1-55786-164-1.

SOUTHERTON, D. Consuming Kitchens: Taste, Context and Identity Formation. Journal of Consumer Culture, 2001, roč. 1, č. 2, s. 179-203. ISSN 1469-5405.

SWARTZ, David. Culture \& Power: The Sociology of Pierre Bourdieu. Chicago: University of Chicago Press, 1997. ISBN 978-0226785950.

SZELÉNYI, Iván. Urban Inequalities Under State Socialism. Oxford: Oxford University Press, 1983. ISBN 978-0198771760.

ŠAFR, Jiří. Skupina majitelů domů a nájemníků. Třídy bydlení? In ŠANDEROVÁ, Jadwiga (ed.). Nerovnosti kolem nás. Analýza utváreni sociálních nerovností v každodenním životě. Pracovni texty. Praha: ISS FSV UK, 2006, s. 77-101.

VACKOVÁ, Barbora. Idea bydlení za městem a koncept zahradního města. In OUŘEDNÍČEK, Martin, Petra ŠPAČKOVÁ a Jakub NOVÁK (eds.). Sub Urbs: krajina, sídla a lidé. Praha: Academia, 2013, s. 37-60. ISBN 978-80-200-2226-4.

WARDE, Alan. Consumption and theories of practice. Journal of Consumer Culture, 2005, roč. 5, č. 2, s. 131-153. ISSN 1469-5405.

WUGGENIG, Ulf. Comments on Chan and Goldthorpe: Pitfalls in Testing Bourdieu's Homology Assumptions Using Mainstream Social Science Methodology. Poetics, 2007, roč. 35, č. 4-5, s. 306-316. ISSN 0304-422X.

\section{Autor}

Ondřej Špaček je odborným asistentem na Fakultě humanitních studií Univerzity Karlovy. Zabývá se sociologií města, sociálními nerovnostmi a kvantitativní metodologií výzkumu. Kontakt: ondrej.spacek@fhs.cuni.cz 